\title{
Irish urban history: an agenda
}

\author{
ERIKA HANNA and RICHARD BUTLER \\ School of Humanities, University of Bristol, 3-5 Woodland Road, \\ Bristol BS8 1TB, UK \\ Centre for Urban History, University of Leicester, 3-5 Salisbury Road, Leicester, \\ LE1 7QR, UK
}

Modern Irish history is urban history. It is a story of the transferral of a populace from rural settlements to small towns and cities; of the discipline and regulation of society through new urban spaces; of the creation of capital through the construction of buildings and the sale of property. The history of Ireland has been overwhelmingly the history of land, but too often the emphasis has been on the field rather than the street, and on the small farmer instead of the urban shopkeeper. But the same questions of property run throughout Irish urban history from the early modern period to the contemporary, as speculators, businesses and government have attempted to convert land into profit, creating new buildings, streets and spaces, and coming into conflict with each other and other vested interests. Indeed, as recent work on Irish cities has shown, a turn to the urban history of Ireland provides a framework and a methodology for writing a textured and complex history of Ireland's distinctive engagement with modernity.

It is over 30 years since Mary Daly published her survey of Irish urban history in this journal; writing in 1986, she examined the successes of a newly developing field in providing new understanding of colonialism, economics and social change, and looked to areas which still needed research. ${ }^{1}$ In the intervening years, urban history has undergone significant intellectual shifts and has received a range of new methods and approaches, with the cultural, material, spatial turns (among others) having a simultaneously energizing and fragmenting impact on the field. In this context, much of Daly's agenda has been completed, while much more - unforeseen at the time - has been achieved. For example, we now know much more about Viking settlements in Ireland. ${ }^{2}$ There have been many local studies on planning and 'improvement' in provincial towns and cities, which have in turn challenged the disproportionate

${ }^{1}$ M.E. Daly, 'Irish urban history: a survey', Urban History Yearbook, 13 (1986), 61-72.

2 See especially H. Clarke (ed.), Medieval Dublin: The Making of a Metropolis (Dublin, 1990); M. Valante, 'Reassessing the Irish "monastic town"', Irish Historical Studies, 31 (1998), 1-18; and M. Valante, The Vikings in Ireland: Settlement, Trade and Urbanization (Dublin, 2008). 
focus of a previous generation of scholars on Dublin. ${ }^{3}$ Furthermore, the political history of provincial municipal corporations is now much better understood. ${ }^{4}$ Historians today should no longer feel the need, as Daly did, to challenge the mid-twentieth-century view that 'towns were somehow alien to Irish culture', or the narrow Irish-Ireland perspective that 'the true Irishman was a peasant'. ${ }^{5}$

The great wealth of scholarship published in the intervening years has both closed old controversies and opened new debates. Following Daly's survey, no fewer than 10 research articles on Irish topics have appeared in the pages of this journal, focused on both early modern and modern periods, and on Irish people living in Ireland and immigrant communities in cities abroad. More than half of these have appeared in just the last five years. ${ }^{6}$ Many other important interventions have been published in the Journal of Urban History and the Journal of Historical Geography. ${ }^{7}$ The growing interest within universities is also evident in

${ }^{3}$ See for example D.A. Murphy, The Two Tipperarys: The National and Local Politics, Devolution and Self-Determination of the Unique 1838 Division into Two Ridings, and the Aftermath (Nenagh, 1994); P.J. Geraghty, 'Urban improvement and the erection of municipal buildings in County Louth during the eighteenth and nineteenth centuries', Journal of the County Louth Archaeological and Historical Society, 23 (1995), 295-317; M. Byrne, 'Tullamore: the growth process, 1785-1841', in W. Nolan and T.P. O'Neill (eds.), Offaly: History and Society (Dublin, 1998), 569-626; J. Mayock, 'William Leeson: Westport's first town planner', Cathair na Mart: Journal of the Westport Historical Society, 18 (1998), 135-42; P.J. O'Connor, 'Growth and development of Co. Limerick's leading towns', in G. Ó Tuathaigh, L. Irwin and M. Potter (eds.), Limerick: History and Society (Dublin, 2009), 257-76; and L. Harrington, 'The work of Cork's Wide Streets Commissioners on Washington Street', Irish Architectural and Decorative Studies, 15 (2012), 98-117.

${ }^{4}$ M. Potter, The Municipal Revolution in Ireland: A Handbook of Urban Government in Ireland since 1800 (Dublin, 2011).

${ }^{5}$ Ibid., 61. See also M.E. Daly, 'An alien entity? Attitudes to the city in late nineteenthand twentieth-century Ireland', Etudes Irlandaises, 11 (1985), 181-94; and J. Valente, 'Introduction', Éire-Ireland (special issue on Urban Ireland), 45:1-2 (2010), 5-10.

6 T.R. Slater, in 'Reviews of books', Urban History, 26 (1999), 415-16; M. McCarthy, 'The forging of an Atlantic port city: socio-economic and physical transformations in Cork, 1660 $1700^{\prime}$, Urban History, 28 (2001), 25-45; P. O'Leary, 'Mass commodity culture and identity: the Morning Chronicle and Irish migrants in a nineteenth-century Welsh industrial town', Urban History, 35 (2008), 237-54; G. McIntosh, 'Symbolizing the civic ideal: the civic portraits in Belfast Town Hall', Urban History, 35 (2008), 363-81; S.J. Connolly, 'Like an old cathedral city: Belfast welcomes Queen Victoria, August 1849', Urban History, 39 (2012), 571-89; M. Flanagan, 'Private needs, public space: public toilets provision in the Anglo-Atlantic patriarchal city: London, Dublin, Toronto and Chicago', Urban History, 41 (2014), 265-90; E. Hanna, 'Seeing like a cyclist: visibility and mobility in modern Dublin, c. 1930-1980', Urban History, 42 (2015), 273-89; O. Purdue, 'Surviving the industrial city: the female poor and the workhouse in late nineteenth-century Belfast', Urban History, 44 (2017), 69-900; C. Breathnach and B. Gurrin, 'A tale of two cities - infant mortality and cause of infant death: Dublin, 1864-1910', Urban History, 44 (2017), 647-77; and C. Wallace, 'Civil society in search of a state: Dublin, 1898-1922', Urban History (FirstView online Apr. 2017).

7 See especially B.J. Graham, 'Urbanization in medieval Ireland, c. AD 900 to c. AD 1300', Journal of Urban History, 13 (1987), 169-96; K.A. Miller, 'Urban immigrants: the Irish in the cities', Journal of Urban History, 16 (1990), 428-41; B.J. Graham and L.J. Proudfoot, 'Landlords, planning, and urban growth in eighteenth- and early nineteenth-century Ireland', Journal of Urban History, 18 (1992), 308-29; H. Clout, 'Streets broad and narrow: reflections on the urban history of Ireland and England', Journal of Urban History, 29 (2003), 
the Éire-Ireland special issue on urban Ireland in 2010, the Society for the Study of Nineteenth-Century Ireland (SSNCI)'s annual conference on 'Urban spaces in nineteenth-century Ireland' at Queen's University Belfast in June 2014 and in the establishment of the Irish Modern Urban History Group soon after. ${ }^{8}$ Moreover, the digital revolution in combination with public history projects of the past decade has forged a golden age for Irish urban history. This has taken many forms; for example, an active coalition of activists, conservation professionals and academics have shared expertise in developing understandings of Irish cities and towns as heritage landscapes. ${ }^{9}$ Coupled with a boom in local history publishing - often to an exceptional academic standard - scholars now have access to the Ordnance Survey, the Folklore Collection, the National Inventory of Architectural Heritage (with its associated GIS mapping interface), County Council heritage projects, radio and TV archives, oral history and a host of blogs and exhibitions. Indeed, some of the most exciting work in Irish urban history - for example the Dublin blog Come here to me! - is now happening outside the supposed ivory tower of academe. ${ }^{10}$

Despite this activity, there are still several aspects of Irish urban history which remain either unexplored or significantly under-researched, and this article seeks to establish a new agenda for today's urban historians. For pre-1900 topics, there are perhaps a dozen aspects of Irish urban history that demand further attention (see below for a post-1900 agenda). First, we need to know more about how social class was both shaped by, and in turned shaped, the history of Irish towns and cities, building on the excellent work by John Cunningham and articles appearing in

504-12; W. Jenkins, 'In search of the lace curtain: residential mobility, class transformation, and everyday practice among Buffalo's Irish, 1880-1910', Journal of Urban History, 35 (2009), 970-97; and M.L. Mullan, 'Sport, culture, and nation among the Hibernians of Philadelphia: Irish American civic engagement and cultural nationalism, 1880-1920', Journal of Urban History, 39 (2013), 579-600. See also B.J. Graham, 'Urban genesis in early medieval Ireland', Journal of Historical Geography, 13 (1987), 3-16; B. Graham and S. Hood, '"Every creed and party"': town tenant protest in late nineteenth-century and early twentieth-century Ireland', Journal of Historical Geography, 24 (1998), 170-87; G. Kearns, 'Mapping Irish colonialism: a round-table', Journal of Historical Geography, 34 (2008), 13866; and D. Dickson, 'Dublin, 1930-1950: the emergence of the modern city' (review), Journal of Historical Geography, 53 (2016), 126-7.

8 The proceedings of the SSNCI conference in Queen's University Belfast in 2014 are forthcoming with Liverpool University Press (2018).

9 R. Ussher, Dawson Street, Molesworth Street and Kildare Street (Dublin, 2009); E. Hanna, Modern Dublin: Urban Change and the Irish Past, 1957-1973 (Oxford, 2013); K. Kearns, Georgian Dublin: Ireland's Imperilled Architectural Heritage (Newton Abbot, 1983); R. O'Byrne, Irish Georgian Society: A Celebration (Dublin, 2008); D. Brett, The Construction of Heritage (Cork, 1996); N. Moore and Y. Whelan (eds.), Heritage, Memory and the Politics of Identity: New Perspectives on the Cultural Landscape (London, 2006).

${ }^{10}$ See for example the local history journals for Galway, Kildare and Cork in particular, and the Galway Community Heritage project (http:/ / galwaycommunityheritage.org). For Come here to me!, see https:/ / comeheretome.com. See also the 2016 exhibition hosted by the Irish Georgian Society in Dublin: 'Ireland's main street, 1625-1925: an architectural history'. 
the Irish labour history journal Saothar (the Irish for 'labour'). ${ }^{11}$ Second, while there has been some research on female philanthropy in Irish cities, we do not know enough about the role that women played in urban agency and sociability, particularly poorer women in smaller cities. In a similar vein, much work remains to be done on the experience of women in both formal and informal employment. ${ }^{12}$ Histories of urban material culture and consumption have, as David Dickson comments in this issue, often given insights into other themes in Irish towns such as gender and sociability. While these have been strongest in Irish eighteenth-century studies, scholars working on other time periods could learn much from the transnational and theoretical nature of their approaches. ${ }^{13}$ The history of mentalities is another subject within Irish urban history that needs sustained focus: what ideas shaped the viewpoints of key urban elites in eighteenth- and nineteenth-century Ireland? And to what extent were the urban landlords, grand jurors and corporation men, who (re)shaped Irish cities and towns, influenced by the broader intellectual agendas of their eras: improvement, modernization, millennialism, nationalism, sectarianism, evangelism, democracy, decline or reform? ${ }^{14}$ How did the Irish city and town act as a site of politics, both local and national? And, perhaps more fundamentally, what is distinctively 'Irish' - and how 'urban' - is Irish urban history?

As regards the twentieth century, the 'Decade of Centenaries' has witnessed an outpouring of academic scholarship and public history

11 J. Cunningham, 'A Town Tormented by the Sea': Galway, 1790-1914 (Dublin, 2004); and J. Cunningham, "'Compelled to their bad acts by hunger": three Irish urban crowds, 181745', Éire-Ireland, 45 (2010), 128-51. For Saothar, see articles by F. D'Arcy, such as 'The decline and fall of Donnybrook Fair: moral reform and social control in nineteenth-century Dublin', Saothar, 13 (1988), 7-21, and J.M. Hearne, 'The cost of living and standard of living of urban workers in Waterford, 1834-56', Saothar, 26 (2001), 37-50.

12 E. McLaughlin, 'Women and work in Derry city: a survey', Saothar, 14 (1989), 35-45; M. Luddy, Women and Philanthropy in Nineteenth-Century Ireland (Cambridge, 1995); and R. Raughter, 'A discreet benevolence: female philanthropy and the Catholic resurgence in eighteenth-century Ireland', Women's History Review, 6 (1997), 465-87.

${ }^{13}$ M.J. Powell, The Politics of Consumption in Eighteenth-Century Ireland (Basingstoke, 2005); C. Casey (ed.), The Eighteenth-Century Dublin Town House: Form, Function and Finance (Dublin, 2010); S. Rains, Commodity Culture and Social Class in Dublin, 1850-1916 (Dublin, 2010); S. Flavin, 'Consumption and material culture in sixteenth-century Ireland', Economic History Review, 64 (2011), 1144-74; C. Lucey, 'Keeping up appearances: redecorating the domestic interior in late eighteenth-century Dublin', Proceedings of the Royal Irish Academy, 111C (2011), 169-92; S. Foster, "'Ornament and splendour": shops and shopping in Georgian Dublin', Irish Architectural and Decorative Studies, 16 (2013), 12-33; A. Fitzgerald, Silver in Georgian Dublin: Making, Selling, Consuming (London, 2016); and S. Rains, 'City streets and the city edition: newsboys and newspapers in early twentieth-century Ireland', Irish Studies Review, 24 (2016), 142-58.

14 See L.J. Proudfoot, 'Place and mentalité: the "big house" and its locality in County Tyrone', in C. Dillon and H.A. Jeffries (eds.), Tyrone: History and Society (Dublin, 2001), 511-42; P. Duffy, 'Colonial spaces and sites of resistance: landed estates in nineteenth-century Ireland', in L.J. Proudfoot and M.M. Roche (eds.), (Dis)placing Empire: Renegotiating British Colonial Geographies (Aldershot, 2005), 15-40; N. Garnham, 'Riot acts, popular protest and Protestant mentalities in eighteenth-century Ireland', Historical Journal, 49 (2006), 403-23; and R. Usher, Protestant Dublin 1660-1760: Architecture and Iconography (Basingstoke, 2012). 
which has amounted to a reassessment of the revolutionary period. Much of this has taken an urban approach to 1916 and its impact, with a fine set of local studies of the impact of war and revolution on the towns and cities across Ireland, with Padraig Yeates in particular tracing in close detail the impact of conflict on the capital. ${ }^{15}$ Just as conflict was profoundly spatial, so too was the consolidation of political power after 1922 materialized and embedded through both new buildings and new suburbs and the renarrativization of extant urban landscapes through statuary and naming, a history which has been explored north and south through memory studies and cultural geography. ${ }^{16}$ The re-emergence of violence in Northern Ireland from the late 1960s has also been understood as a conflict profoundly rooted in place and the politics of space, and much of the enormous quantity of scholarship on the province has employed an urban framework - implicitly and explicitly - for making sense of these events. ${ }^{17}$ But despite the richness of new work on the twentieth-century city, much remains to be done. Indeed, while modern Ireland's distinctive pattern of dispersed settlements, provincial towns and sprawling housing estates has been recognized, much more could be explored to understand them fully. For example, there is a need for more detailed studies of the economic and demographic aspects of Irish cities and towns - again especially provincial cities and smaller towns. ${ }^{18}$ Furthermore, there is little

15 P. Yeates, A City in Wartime: Dublin 1914-1918 (Dublin, 2011); P. Yeates, A City in Turmoil: Dublin 1919-1921 (Dublin, 2012); P. McCarthy, Waterford: The Irish Revolution 1912-1923 (Dublin, 2015); J. Borgonovo, The Dynamics of War and Revolution: Cork City 1916-1918 (Cork, 2013).

16 Y. Whelan, Reinventing Modern Dublin: Streetscape, Iconography, and the Politics of Identity (Dublin, 2003); Y. Whelan, 'The construction and destruction of a colonial landscape: monuments to British monarchs in Dublin before and after independence', Journal of Historical Geography, 28 (2002), 508-33; A. Greer, 'Sir James Craig and the construction of new parliament buildings at Stormont', Irish Historical Studies, 31 (1999), 373-88; J. Crowley and D. Ó Drisceoil, Atlas of the Irish Revolution (Cork, 2017); J. Donnelly Jr, "'Unofficial" British reprisals and IRA provocations: the case of three Cork towns', ÉreIreland, 45 (2012), 152-97; A. Dolan, Commemorating the Irish Civil War: History and Memory, 1923-2000 (Cambridge, 2003); N. Johnson, Ireland, the Great War, and the Geography of Remembrance (Cambridge, 2003); R. McManus, Dublin 1910-1940: Shaping the City and Suburbs (Dublin, 2002); J. Brady, Dublin 1930-1950: The Emergence of the Modern City (Dublin, 2014); E. Rowley, 'The architect, the planner and the bishop: the shapers of "ordinary" Dublin, 1940-60', Footprint: Delft Architecture Theory Journal, 17 (2015), 69-88; E. Rowley, 'Transitional modernism: post-war Dublin churches and the example of the Clonskeagh church competition, 1954', in C. Taffe and E. Keown (eds.), Irish Modernism: Origins, Contexts, Publics (London, 2009).

17 S. Prince, Belfast and Derry in Revolt: A New History of the Start of the Troubles (Dublin, 2011); N. O Dochartaigh, From Civil Rights to Armalites: Derry and the Birth of the Irish Troubles (Basingstoke, 2005); P. Doherty and M. Poole, 'Ethnic residential segregation in Belfast Northern Ireland, 1971-1991', Geographical Review, 87 (1997), 520-36; L. McAtackney, 'Peace maintenance and political messages: the significance of walls during and after the Northern Irish "Troubles"', Journal of Social Archaeology, 11 (2011), 77-98; G. Dawson, 'Trauma, place, and the politics of memory: Bloody Sunday, Derry, 1972-2004', History Workshop Journal, 59 (2005), 151-78.

18 An important recent work is P. Connell, 'From hovels to homes: the provision of public housing in Irish provincial towns, 1890-1945' (Ph.D. thesis, Trinity College Dublin, 2017). 
work that adequately theorizes their distinctive culture; from the ways in which buses and bicycles connected rural communities, to the sociability of the pub, and the politics of neighbourhood, there is a large amount of work which could be done to make sense of the micro-geographies of social change.

On a larger scale, the urban history of Ireland could also benefit from a turn to the transnational. Irish cities and towns have always operated as sites of movement, drawing in rural populations and operating as nodal points through which people have migrated to cities all over the globe, forming distinctive Irish urban communities wherever they went. ${ }^{19}$ Inversely, cities were also places of reception: of people, culture and capital. In central Dublin, fiscal incentives and neo-liberal urban forms, such as Temple Bar and the International Financial Services Centre, transformed both the city's landscape and economic profile, while midsized towns across Ireland were also part of this process, reconfigured by the arrival of enterprise zones and architectural set pieces. ${ }^{20}$ This story has been told through the economics of square footage and rental income; however, Ireland's urban history in global context still waits to be written. 21

In this issue, Niamh NicGhabhann asks us to analyse the role that religion played in Irish urban life and architectural development. Considering how important Roman Catholic social and moral teaching were in nineteenth-century Ireland, it is surprising how rarely Irish urban scholars have engaged with the broader European literatures of Catholic urban planning and the extent to which morphological, architectural and social developments in Irish towns fitted within what intellectual historians have termed 'Catholic modernity' (often understood as analogous, though not unproblematically, with Emmet Larkin's concept

19 See for example W. Jenkins, Between Raid and Rebellion: The Irish in Buffalo and Toronto, 18671916 (Québec, 2013); D.M. MacRaild, Culture, Conflict and Migration: The Irish in Victorian Cumbria (Liverpool, 1998); and S. Cooper, 'Irish migrant identities and community life in Melbourne and Chicago, 1840-1890' (Ph.D. thesis, Edinburgh, 2017).

${ }^{20}$ C. O'Callaghan and D. Linehan, 'Identity, politics and conflict in dockland development in Cork, Ireland: European Capital of Culture 2005', Cities, 24 (2007), 311-23; D. Bayliss, 'Creative planning in Ireland: the role of culture-led development in Irish planning', European Planning Studies, 12 (2004), 497-515; D. Payne and P. Stafford, 'The politics of urban regeneration in Dublin', in J.R. Gupta (ed.), Urban Development Debates in the New Millennium (New Delhi, 2005), 98-110; N. Moore, Dublin Docklands Reinvented: The PostIndustrial Regeneration of a European City Quarter (Dublin, 2008).

21 M. Bannon, Office Location in Ireland: The Role of Central Dublin (Dublin, 1973); M. Bannon, 'Office concentration in Dublin and its consequences for regional development in Ireland', in P.W. Daniels (ed.), Spatial Patterns of Office Growth and Location (Chichester, 1979); P. Malone, 'Dublin: motive, image, and reality in the Custom House Docks', in P. Malone (ed.), City, Capital and Water (London, 1996); A. McLaren and S. Kelly (eds.), Neoliberal Urban Policy and the Transformation of the City: Reshaping Dublin (London, 2014); R. Kitchin, C. O'Callaghan, M. Boyle, J. Gleeson and K. Keaveney, 'Placing neoliberalism: the rise and fall of Ireland's Celtic Tiger', Environment and Planning A, 44 (2012), 1302-26. 
of a 'devotional revolution'). ${ }^{22}$ And more generally, despite recent publications in journals such as Irish Architectural and Decorative Studies and the monthly blog of the National Inventory of Architectural Heritage, the process by which streets in Irish provincial towns were planned and built remains an under-researched topic. ${ }^{23}$ With unprecedented access to census material, estate papers and historic maps now freely available online, a new generation of scholars is well placed to enhance greatly our knowledge on these critical aspects of town formation and growth.

Irish urban history is a relatively under-theorized subject. Many practitioners have been more at ease in deeply empirical local or national studies than in negotiating unfamiliar approaches, concepts or typologies. Two exceptions to this general trend have been in disputes within studies of Viking and early medieval Ireland (as mentioned above), and in the frameworks set out by Lindsay Proudfoot and Brian Graham in their immensely useful but often overlooked articles and books published on Irish towns between the late 1980s and late 1990s. ${ }^{24}$ As Dickson notes, both subjects have, in different ways, engaged with critical concepts of definition and typology: what constituted a town in different time periods, what makes towns in Ireland distinctly 'Irish', how urban agency was expressed and what the relationship was between property and urban life. Proudfoot and Graham's studies provide an avenue for further theoretical development. Finally, the historiography of Irish urban history itself remains an under-studied field. Dickson, in this issue, makes amends for this deficit, but the only major hitherto published comparative study of Irish urban histories in the eighteenth and nineteenth centuries remains a thought-provoking chapter by Rosemary Sweet, published 15 years ago. ${ }^{25}$

As this summary demonstrates, the urban history of Ireland is a multifaceted field, and across its many variations it has opened up a

${ }^{22}$ For a recent overview, as discussed by NicGhabhann, see J. Janssen, 'Religiously inspired urbanism: Catholicism and the planning of the southern Dutch provincial cities Eindhoven and Roermond, c. 1900 to 1960', Urban History, 43 (2016), 135-57. For 'Catholic modernity', see R. Schaefer, 'Program for a new Catholic Wissenschaft: devotional activism and Catholic modernity in the nineteenth century', Modern Intellectual History, 4 (2007), 43362; B. Vilallonga, 'The theoretical origins of Catholic nationalism in nineteenth-century Europe', Modern Intellectual History, 11 (2014), 307-31; and E. Larkin, 'The devotional revolution in Ireland, 1850-75', American Historical Review, 77 (1972), 625-52.

${ }^{23}$ For example, Lucille Ellis' blog post on Bindon Street, Ennis, Co. Clare, published on the National Inventory of Architectural Heritage website in Aug. 2015 (http://www. buildingsofireland.ie).

24 B.J. Graham and L.J. Proudfoot, Urban Improvement in Provincial Ireland, 1700-1840 (Athlone, 1994); L.J. Proudfoot, Urban Patronage and Social Authority: The Management of the Duke of Devonshire's Towns in Ireland, 1764-1891 (Washington, DC, 1995); L. Proudfoot, Property Ownership and Urban and Village Improvement in Provincial Ireland, c. 1700-1845 (London, 1997).

25 R. Sweet, 'Provincial culture and urban histories in England and Ireland during the long eighteenth century', in P. Borsay and L. Proudfoot (eds.), Provincial Towns in Early Modern England Ireland: Change, Convergence, and Divergence (Oxford, 2002), 223-40. See also D. Dickson, Dublin: The Making of a Capital City (Cambridge, MA, 2014), bibliographical note, 655-69. 
host of new ways of understanding Ireland. A turn to the history of Irish towns and cities has provided historians with a form for understanding, with nuance and detail, the ways in which individuals and groups have attempted to modernize Ireland, and how these processes have been accommodated and resisted. Moreover, the survival of older buildings and spatial forms, and the delays of reconstruction, have shown how these processes are often uneven and delayed, and operate in practice in far more complex ways than imagined in discourse. An attentiveness of the politics of space, a focus on materialities and an exploration of flows of people and capital provide new paradigms for making sense of the country which can both add to long-running debates and generate new research questions. Indeed, in today's Ireland, where questions of housing, infrastructure and ownership continue to dominate social and political formations, it is crucial that we continue to develop the tools to interrogate these processes historically and situate these themes as central to making sense of Ireland's distinctive past.

The articles included in this special section came out of a symposium entitled 'The State of Irish Urban History' held at the Centre for Urban History, University of Leicester in April 2016. As detailed above, Dublin and Belfast have already received considerable attention, and in this context the articles here turn their focus on Ireland's less-studied urban centres. David Dickson's article sets the scene for the following empirical studies with a consideration of the writing of Irish urban history in the 1820 s and in the 1980s. Dickson explores these two short-lived periods of enthusiasm for urban history in Ireland as a way of making sense of how the discipline has fitted into a wider national historiography. Using a Foucauldian framework, Peter Hession explores market reform in nineteenth-century Ireland. Taking Cork as his case-study, he shows how local elites and state bureaucrats increasingly worked together to regulate, cleanse and police the boundaries of markets, and so draw the agrarian population into a broader capitalist system. In doing so, he highlights the extent to which Irish urban history is intricately tied to the relationship between urban and rural. Ruth McManus explores efforts to alleviate housing shortages in the years immediately following independence, with a particular focus on the town of Ballina in Co. Mayo. She shows how financial impediments, national legislation and local politics combined to create the town's distinctive social geography. Finally, Niamh NicGhabhann's article explore rituals surrounding consecration and the laying of the foundation stone across Munster with a particular focus on St John's Cathedral in Limerick. She shows how these parades and ceremonies were used to reinforce the increasing social, economic and political power of the city's Roman Catholic community. Taken together, these articles signal new directions, methods and theories for the writing of Ireland's urban history. 